September 2006

\title{
The Agency of "Triggering Mechanisms" as a Factor in the Organization of the Genocide Against the Armenians of Kayseri District
}

Vahakn N. Dadrian

\section{Recommended Citation}

Dadrian, Vahakn N. (2006) "The Agency of "Triggering Mechanisms" as a Factor in the Organization of the Genocide Against the Armenians of Kayseri District," Genocide Studies and Prevention: An International Journal: Vol. 1: Iss. 2: Article 4.

Available at: https://digitalcommons.usf.edu/gsp/vol1/iss2/4

This Articles is brought to you for free and open access by the Open Access Journals at Digital Commons @ University of South Florida. It has been accepted for inclusion in Genocide Studies and Prevention: An International Journal by an authorized editor of Digital Commons @ University of South Florida. For more information, please contact digitalcommons@usf.edu. 


\title{
The Agency of "Triggering Mechanisms"' as a Factor in the Organization of the Genocide Against the Armenians of Kayseri District
}

\author{
Vahakn N. Dadrian \\ Zoryan Institute
}

\begin{abstract}
Using the notion of a "triggering mechanism" as a guidepost, this article details the sequence of events precipitated by the accidental explosion of a bomb a young Armenian was tinkering with in anticipation of a new round of massacres he hoped to obviate. The ensuing massive and indiscriminate arrests throughout the length and breadth of the district, the attendant use of a variety of methods of torture, and the eventual eradication of the bulk of the district's Armenian population through courts-martial, followed by serial executions through hanging, deportation, and massacre, are depicted and analyzed to demonstrate the exterminatory thrust of the ensemble of the counter-active governmental measures. The study concludes that the accidental explosion of the bomb was a welcome opportunity for the perpetrators, directed by the local leaders of the monolithic political party, the Committee for Union and Progress (CUP), to proceed with their pre-existing germinal plan of regional genocide.
\end{abstract}

\section{Introduction}

Generally, in conflictual intergroup relations, powerful perpetrators facing relatively weak victims tend to rely on a number of standard techniques to either rationalize or justify their criminal acts. One such technique is provocation. ${ }^{1}$ The victims' patience and endurance is insidiously taxed to the limit, forcing them, if possible, to resist the provocation effectively. Another technique relates to the sudden commission of a violent act by a member of the victim group, which signals ominous intent to the perpetrator group and is seized by it as a pretext for repression. Absent an existing and simmering conflict between these two antithetical groups, the incident, as a rule, might lend itself to localization and be handled accordingly. But that very simmering conflict and the advantage of the huge power differential accruing to the potential perpetrator group favor the latter's resort to opportunism. Deliberate acts of provocation by powerful antagonists always involve calculations, seeking favorable vantage grounds for projected future actions; hence, they are driven by goal-directed opportunism. Within the context of perpetrator-victim conflicts, such acts of provocation tend to acquire a circular thrust that is propelled by the perpetrator. By way of aggressive and threatening behavior, the potential perpetrator intentionally produces a level of provocation strong enough to drive the potential victim to respond, in turn, in a way that is conveniently defined by the former as provocation. Conditions of acute crisis in interethnic or international relations afford just such opportunities, whereby the more powerful party to the conflict can proceed to provoke in order to be provoked subsequently. In brief, the welcome eruption of a crisis combines with

Vahakn N. Dadrian, "The Agency of "Triggering Mechanisms" as a Factor in the Organization of the Genocide Against the Armenians of Kayseri District." Genocide Studies and Prevention 1, 2 (September 2006): 107-126. (C) 2006 Genocide Studies and Prevention. 
the substantial vulnerability of the group with which the precipitator of the crisis is identified to create the triggering mechanism for a magnified response to it.

The initiation of a genocidal campaign in the Kayseri district exemplifies the lethal role such triggering mechanisms can play, especially under conditions of acute international conflict. An outlying district of Ankara province in central Turkey, at the foot of snow-capped Mt. Erciyas and bestriding the course of Kizılırmäk River immediately below Sivas, Kayseri first emerged in history as Caesarea when Emperor Tiberius took possession of Cappadocia in 17 CE. In 1419, Sultan Selim I incorporated Kayseri into the Ottoman Empire. In this context it is tempting to refer to the assassination by a Jewish youth of Ernst vom Rath, a third secretary in the German embassy in Paris, on 7 November 1938. This incident unleashed a violent antiJewish campaign that eventually culminated in the World War II Jewish Holocaust. Central to that genocidal response was the way the Nazis chose to define the crisis precipitated by the assassination. An editorial in Völkischer Beobachter, the organ of Nazi Propaganda Minister Joseph Göbbels, declared on 9 November 1938, one day after the death of Rath, "The German people are entitled to identify the Jews in Germany with this crime." Three days later at a conclave attended by top Nazi leaders, including Göbbels, Reinhard Heydrich, Interior Minister Wilhelm Frick, and Economics Minister Walther Funk, Herman Göring, who was chairing the meeting, made a dramatic announcement. Göring declared that in the course of lengthy discussions that he had held with Hitler for two days following the antiJewish Kristallnacht riots of 10 November, Hitler had issued an order "requesting that the Jewish question be now, once and for all, coordinated or solved one way or another."2 Even though the Final Solution (Endlösung) would require nearly three more years to evolve and to materialize, the incident of the assassination helped precipitate matters not only in terms of administrative policies but also in terms of public agitation and incitement. The Nazi co-optation of the German public is intimately linked with the broader functions of the triggering mechanism at issue here.

Within this general purview, this study proposes to examine the role of a similar incident in the precipitation of cataclysmic events that entailed the violent liquidation of the entire Armenian population of the Kayseri district during World War I. Driven by personal revenge, like the Jewish youth mentioned above, a young Armenian who had witnessed the slaughter of his relatives during the Sultan Abdul Hamit-era massacres was tinkering with a homemade bomb when it suddenly and prematurely exploded, simultaneously killing him and creating havoc in his Armenian neighborhood. The severity of the authorities' response is revealed in the draconian measures they instituted against the entire Armenian population of the district. Everek, the town where the bomb went off, was but a sub-unit of that district. The mass arrest, torture, and execution of hundreds of its Armenian inhabitants, on the one hand, and the murderous deportation of the rest of district's Armenian population, on the other, formed part of these measures. The focus of this study will be on assembling the details of the retaliatory response by the authorities with a view to demonstrating the underlying genocidal thrust and aim.

\section{Kayseri's Governmental Set-Up and the Distribution of Its Armenian Population}

Until its final dissolution in 1923, when the new Turkish Republic was inaugurated, the Ottoman Empire for centuries was run on a system of provincial administration 
whose level and degree of control by a central authority often depended upon the nature of that authority. The more autocratic or despotic the central authority, the stricter and more pervasive its control proved to be, especially in the area of conflict with the national minorities that constituted a large segment of the multiethnic empire.

Because the bulk of the Armenian population of the Ottoman Empire was located in its Asiatic provinces, the organization and function of this Ottoman provincial administration bore heavily on the type of treatment the empire's Armenian population in general, and Kayseri's in particular, received during the war. It might, therefore, be useful to provide here a sketch of that administrative system. The highest civilian authority was vested in a governor-general (vali) who presided over the governmental affairs of a province (vilayet). The number of provinces constituting the empire changed often because the empire kept shrinking, fluctuating between twentyeight and thirty-six. The provinces, in turn, were partitioned into districts (liva or sancak), which were run by district governors (mutassarrif). The districts were further divided into counties (kaza) governed by county executives (kaymakam), who, more often than not, were religious judges $(k a d i) .{ }^{3}$ The counties were further subdivided into townships (nahiye) comprising groups of small rural villages, each of which encompassed at least twenty families; these were governed by an administrator (müdir). The smallest administrative unit was the karye, the village, comprising about forty or fifty houses and administered by a headman (muhtar).

There functioned as an accessory component of this provincial administrative system, however, an adjunct group of so-called independent districts. The designation "independent" denoted the idea of a status interposed between a province and a district and connoted that of an administrative link with either a province or a county. ${ }^{4}$ On 20 April 1914 (a few months before the outbreak of World War I), Kayseri was granted the status of an independent district ${ }^{5}$ by Interior Minister and Committee of Union and Progress (CUP) ruling party boss Mehmet Talât. Still maintaining some links with the administration of Ankara province, from which it had been detached and declared independent, Kayseri district comprised four sub-units (i.e., counties): its capital, Kayseri, plus the other counties of Bünyan, Develi (also called Everek), and Incesu. Because of their proximity to each other, Develi (or Everek) and Fenese were often lumped together as twin cities; Armenians mostly used the Everek-Fenese twin designation. Combined together, these four counties encompassed some 200 sub-units (i.e., townships and villages) containing a sizeable Armenian population. Altogether, Kayseri district had ninety-eight villages, twenty-four of which were attached to the district's capital, Kayseri. ${ }^{6}$

According to official Ottoman statistics released in 1914, Kayseri district's total Armenian population was 52,192 persons, of whom 48,659 belonged to the Gregorian-Apostolic Mother Church; 2,018 were Armenian Protestants; and 1,515 were Armenian Catholics. ${ }^{7}$ Armenian community life was, by and large, organized around a network of thirty-two churches and thirty-one affiliated parishes. ${ }^{8}$

\section{Triple-Layered Authority in Wartime Kayseri}

As in every other part of the Ottoman Empire, three distinct kinds of authority held sway in Kayseri during the war. The principal domain, of course, was civilian provincial administration, the make-up of which is outlined above. A network composed of a district governor, four county executives, and several administrators and headmen was in charge of the mundane affairs of the district. Moreover, because 
of the ongoing war and the incidence of martial law, the military had gained a foothold in the power structure of the entire district. It not only took care of such matters as recruitment, logistics, and transport but handled two additional matters that would have grave consequences for the Armenians: exorbitant requisitions, of all kinds and at all levels, and the administration of military justice through courts-martial.

The overall authority for all these matters except court-martial devolved upon Colonel Şahabeddin, the military commander of Kayseri district as well as the Deputy Commander of the 15th Infantry Division, with headquarters in Kayseri city. Moreover, Şahabeddin supervised the operations of the sub-units of the region's gendarmerie regiment that served as the principal escort-guards of the many Armenian deportee convoys. Accordingly, he regularly reported on the massacres attending these rounds of deportation to Colonel Halil Recayi, his superior, who was also the Deputy Commander of Ankara's 5th Army Corps, of which Kayseri's 15th Division was a sub-unit. As to the Military Tribunal sitting in Kayseri city and serially court-martialing the hundreds of Armenians of the district in the wake of the explosion, typically it functioned as an ad hoc instrument of military justice.

As to the third component of the structure of authority in Kayseri district, it may be readily argued that it represented the most potent and, therefore, the most formidable matrix of power in the entire configuration. This component was the CUP's omnipotent party organization, whose superordinate functionaries had, as in other parts of the provinces, the final say in determining the collective fate of Kayseri's Armenians. They were part and parcel of a kind of power structure akin to an iceberg: its submerged part packed all the power needed to conspire, organize, and execute mass murder. In this sense they ultimately proved themselves to be the controlling agents of the direction of the cataclysmic events triggered by the explosion of the bomb described above. Indeed, acting in tandem with Atıf, Ankara province's provisional governor-general, Hüseyin Necati, CUP's regional functionary, discreetly transmitted to the district's civilian authorities that politburo's inexorable directive: the objective of the deportations was the annihilation of the deportee population. ${ }^{9}$

As will be described below, Kayseri district's governor, Aziz Zekâi (Apaydın), himself a CUP functionary, did implement this directive when ordering the exterminatory liquidation of the hundreds of Armenians court-martialed, convicted, and sentenced to long terms of hard labor and prison-in addition to the fifty-five sentenced to death by hanging.

As might be expected, because of turf wars, personality conflicts, and other discordant variables, the relationships of the three power tiers were not always smooth. Despite the developing frictions, however, they did, in the main, know how to coordinate their actions in a cooperative spirit. In the final analysis, the supremacy of CUP party leverage and the iron discipline flowing from it were factors in ensuring the optimal success of the central goal of annihilation.

\section{Precipitation of the Sweeping Crisis}

The crisis in question was set off on 24 February 1915 (11 February according to the Ottoman calendar in use at that time) by the accidental explosion of a homemade bomb with which a young Armenian was tinkering in his home. Having migrated to the United States some years earlier, Kevork Hampartzoumian, also known as Defjian, had recently returned to his native town of Everek, located some twenty-five miles south of Kayseri city. A solitary and melancholy youth, he had witnessed the ghastly 
murders of his brother and uncle during the 18 November 1895 massacre, though he himself had miraculously survived the carnage. It was reported that the fear of imminent new massacres had agitated him enough to try to equip himself with the means of "defensive resistance." The subsequent 1909 Adana massacre and the intensification of the anti-Armenian campaign in the pre-World War I period served to amplify these fears. It appears that exasperation and a measure of despair drove Hampartzoumian to a recourse that would soon prove as reckless as it was perilous for the district's Armenian population. Severely wounded and in excruciating pain, he eventually succumbed to his injuries. ${ }^{10}$

Given the solitary and secretive nature of Hampartzoumian's venture, the Armenians of the town were both frightened and surprised by the incident. Aware of the enormous danger hovering over the Armenian community as a whole, its leaders, for a very brief period, succeeded in hushing up the incident. Even Adil Bey, the kaymakam on duty in Everek, went along with this initiative, as he did not consider the matter of critical importance, given the law-abiding reputation and record of the town's Armenian population. The understanding was that a reckless individual with no organizational ties or support whatsoever had indulged in a dangerous adventure.

Nevertheless, it did not take very long for the district's central authorities to learn about the explosion, and they intervened immediately and with a vengeance. A handyman employed in the local bakery (by a remarkable coincidence, the only Turk residing in that Armenian neighborhood) contacted higher authorities to inform them about the explosion. The investigation that ensued resulted in an official report, a copy of which was relayed to Interior Minister Talât. The die was cast. Everek's kaymakam was immediately dismissed and was replaced by Salihzeki, who was not only his deputy but also the kaymakam of the neighboring smaller town of Incesu. After taking up his position on 4 March 1915, Salihzeki launched a fierce and sweeping investigation. Starting with the arrest of the bomb-maker's family members, relatives, and even casual acquaintances, and continuing with the arrest of Armenians who had returned from America for short visits, Salihzeki extended the number of arrests to include hundreds of other Armenians in neighboring villages and towns, the district's capital city, and other major cities of the empire, including its capital, Constantinople. The Armenians arrested were from all walks of life, including many priests and even the prominent Armenian parliamentarian Mourad (Hampartzoum Boyajian), a member of the Ottoman Chamber of Deputies, the parliament's lower house-in total disregard of his parliamentary immunity.

What followed was an intense regime of torture manifested in various forms. As one survivor averred, Everek's prison was transformed into "Dante's Inferno."11 Within a short time the other prisons of the district, such as Incesu, Comakhlu, and especially the dungeon of Cafer Bey police station in the district's capital, Kayseri city, followed suit. ${ }^{12}$ Ostensibly, the main purpose of this regime of terror was to extract as many confessions as possible regarding substantial caches of arms, weapons, and explosives. The main technique was the gradual intensification of pain. Using the bastinado method, for example, 300 slashes would be administered to the soles of the victim's feet; in cases of sustained resistance and recalcitrance, however, that number would be doubled. Among the victims were some who lost their minds, while others committed suicide in prison and still others were crippled beyond repair. The torture of Deputy Mourad is noteworthy in this respect:

Thrown to the ground, he was administered slashes to his feet, his back, his ribs until such time as, unconscious, he would end up resembling a cadaver. After having been 
revived through the application of cold water, he vainly would be warned-and the tortures would be resumed and continued for three days, until his ravaged body was thrown into the prison's hospital... Mourad was adamant about his rights and his refusal to yield to violence. ${ }^{13}$

His superhuman endurance led one of the chieftains of the brigand bands participating in the massacre of Kayseri's Armenian population to express his admiration of such uncommon intrepidity. ${ }^{14}$

An ancillary and perhaps equally potent driving force in the resort to torture was the insistence of Salihzeki and his cohorts on obtaining lists and names of presumed accomplices. In one case, the subject, unable to endure

the torture hour and after hour, for so many days on end, that...blurted out, "Yes, that is the way it was." But this confession did not bring respite. The tortures continued. The aim was to get [him] to reveal the names of accomplices... The resulting brutality knew no bounds. At one point he became so exasperated that he exploded. "Take me to him [Salihzeki]. I have things to confess." When the police ushered him into the latter's room, he smashed one of the windows with his fist, and with a morsel of broken glass slashed his own stomach and fell down unconscious. ${ }^{15}$

When the same procedure similarly failed to elicit information from another subject, likewise totally unconnected with the bomb and related acts of conspiracy, Salihzeki, unable to contain his frustration and rage, "had the prisoner bound up hands and feet and had him thrown from the prison roof to the cobblestone yard below."16

The sequence of events demonstrated nevertheless that Everek's governor had a plan of his own. He was determined to show his superiors-thereby receiving the requisite accolades and rewards-that he had uncovered a widespread Armenian conspiracy to sabotage the Ottoman-Turkish war effort in pursuit of certain goals set forth by the two Armenian political parties, the Hunchaks and the Dashnaks. ${ }^{17}$ The crisis precipitated by the above-described explosion afforded wide-ranging opportunities to pursue and successfully carry out this agenda. Foremost among these opportunities was the atmosphere of pervasive hostility directed against the Armenians, which had been prevalent in the district since before World War I. As one historian of Kayseri Armenians points out, with the outbreak of World War I, the Turkish authorities began doing everything they could to provoke the Armenians of Kayseri:

In order to agitate the Turkish mobs, they needed to disseminate the story of an Armenian uprising. The ruinous requisitions, the brutal treatment of Armenian conscripts, the scandalous methods of house searches, and the severity of attendant punitive methods had pushed the victim population to paralyzing despair. We, the Armenians, were bracing ourselves for the terrible fate awaiting us. ${ }^{18}$

However, the conditions described above were necessary but not sufficient for the implementation of the plan of wholesale liquidation of the district's Armenian population. Other contingencies also need to be considered.

\section{The Devastating Role of Armenian Informers}

One of these contingencies involved the successful co-optation of Armenian informers. Given religious, linguistic, and related cultural differences that often served to maintain cleavages between Armenian and Turkish communities, the authorities had very little access to the inner workings of Armenian community life. But the terror applied in Everek by Salihzeki, the new kaymakam, soon yielded unexpected results. 
Two prominent local Armenians were co-opted to serve as informers for Salihzeki. In order to enshrine their loyalty and their fidelity to the state, both of them converted to Islam and adopted Turkish names. ${ }^{19}$

With the active and eager help of these two convert-informers, the authorities first obtained a list of all members of Kayseri district's Hunchak political party. They then secured the membership list of the Armenian General Benevolent Union, an organization solely and entirely dedicated to charity work and, in this sense, a decidedly apolitical body. Based on the information in these lists, a program of massive arrests was launched, and it was carried out with inexorable severity. The grip of the arrests extended to such other villages as Incesu, Çomakhlu, and Tomarza and, inevitably and ultimately, to Kayseri city itself. Hundreds of Armenians from all walks of life were taken into custody and, without any formalities or even the pretense of formalities, were cast into the dungeons of the district's various prisons.

This act of co-optation was replicated in Kayseri city itself when the head of that city's Hunchak party agreed to hand over to the authorities all the party's records and registers. Because the Hunchak party had been recognized by the Ottoman government as a legitimate political party, its leadership, unlike that of the rival Dashnak party, did not have a sense of urgency relative to the need for secrecy and concealment. Contrary to expectations, however, the authorities proceeded to arrest not only the officially registered members of the Hunchak party but also their male and female relatives, including their children. ${ }^{20}$ They were assisted in this task by three additional informers in Kayseri. ${ }^{21}$

The fate of all those taken into custody was in fact sealed when the two original informers from Everek signed a statement declaring that there was a definite plan of Armenian conspiracy. Its aim was, they asserted, an uprising to be spearheaded by the leaders of the two political parties, Hunchak and Dashnak. This declaration prompted Salihzeki to push for the adoption by the Turkish government of a radical policy of persecution and subsequently the framing of a major criminal charge against the Armenians. The essence of the accusation was that the caches of arms uncovered during the investigation were intended for an organized rebellion against the government. $^{22}$

Despite their persistent and massive investigations, however, the authorities could not move beyond the discovery of arms caches to establish, by any credible or substantive evidence, that there was any plan of insurgency on the part of any Armenian faction or party. Nor could they establish any link at all between the incident of the bomb and either of the political parties. Perhaps the most bizarre and wanton aspect of the anti-Armenian campaign at this stage was the arrest and torture of multitudes of Armenians, including women and children, who had absolutely no connection with politics, let alone with conspiracy of any sort. But as the discussion below will indicate, these draconian measures were the signposts of an insidious covert scheme targeting the entire Armenian population of the district.

\section{Escalated Incrimination: The Government Plants Bombs in Armenian Residences}

The government's firm resolve to implicate Armenians collectively in the discovery of concealed caches of arms and explosives was pursued in the twin cities of EverekFenese with such ferocity that some Armenians resorted to an unusual step: they began to pay exorbitant prices to Turkish neighbors for handguns, only to surrender 
the weapons to the authorities tormenting them. ${ }^{23}$ The authorities in Kayseri city, emulating the procedures followed in the twin cities, proved equally ferocious. Like Salihzeki, they too were trying to impress Interior Minister Talât in Istanbul. But the value of these acts of overzealousness hinged on tangible results.

Accordingly, A. Midhat, then the mutassarrif of Kayseri district, embarked on a plan to secure, one way or another, caches of arms. He approached and persuaded Bishop Khosrov, the district's Armenian primate, to have the caches surrendered in return for "a benevolent treatment by the government." Enthused by this proposal, the bishop convened the district's Armenian Provincial Council, urging the delegates to comply. But the two Hunchak and Dashnak leaders, who were invited to the meeting for consultation, advised against such compliance. They argued that this was a Turkish trap into which Armenians had fallen time and again, each time paying dearly as a result. Notwithstanding, the council unanimously voted for compliance to demonstrate its loyalty to the government. In line with this attitude, Garabed Camjian, the council's president, went so far as to threaten to assist the government in challenging all those who might dare to contravene the collective will of the Armenian community, as duly represented by the council. ${ }^{24}$ Nevertheless, for a variety of reasons, the council's decision could not be carried out effectively.

Irrespective of all these Armenian efforts to comply with the demands of Turkish authorities, however, the district's central government evidently had its own plan. Straight compliance by the Armenians might disrupt, if not pre-empt, that plan. Accordingly, a plot was hatched with a view to gravely incriminating the Armenians as lethal conspirators. The district governor, along with Kayseri's police chief, Zeki, and, equally important, CUP's regional representative, Cemil Yakub, conspired to have a number of bombs planted in the residence and vineyards of a local Armenian. ${ }^{25}$ The ensuing explosions produced the intended results. ${ }^{26}$

As the Armenians, bewildered and frightened, sought refuge in their homes, the house where the bomb had been planted was immediately surrounded by prepositioned police and gendarmes, led by the police chief, Zeki. Nothing incriminating was found in the house, which was thoroughly searched following the explosion. But the other bombs, planted in the vineyards, were "discovered." The Turkish mobs, already aroused by inflammatory stories about the previous bomb explosion in Everek, were ready to pounce upon the Armenians. A similar scheme was brought to bear upon the above-mentioned Garabed Camjian, the chairman of Kayseri's Armenian Provincial Council (see note 24). Having surreptitiously entered the basement of his house, a team of policemen planted a bomb and a handgun there. By pre-arrangement, a second team then proceeded to "discover" these weapons, following a search that caused the desired pandemonium. ${ }^{27}$

What is so remarkable about these two men who were so deceitfully incriminated is that neither was politically active, not to mention involved in anti-Turkish political activity. As one contemporary author observed of the first case, "In reality the poor man was a totally ignorant person, quite indifferent toward national affairs and, therefore, unaware even of the existence of revolutionary activity."28

As Salihzeki had done in Everek, Zeki prepared an invidious report in which this totally apolitical man was depicted as an integral part of an Armenian conspiracy. The stage was now set to implement a plan of massive arrests. Because of their pre-eminence among the arrestees, it is necessary to review briefly the attitudes and related actions of the district's Armenian political leaders. 


\section{The Stance of Armenian Political Leaders}

The episodes of anti-Armenian massacres predating World War I left their imprint on many Kayseri Armenians. The main lesson they drew from these episodes was the realization that defenselessness creates all the conditions of perilous vulnerability, which, in turn, emboldens potential perpetrators. During the 1894-1896 Sultan Abdul Hamit-era massacres, and subsequently during the 1909 two-tier Adana massacres, which together claimed some 200,000 Armenians, directly and indirectly, this condition of total vulnerability proved decisive. However, Kayseri Armenians had sustained relatively minor losses during the November 1895 massacre and completely averted a similar massacre in 1909 for which "thousands of slaughterers in baggy pants armed to the hilt... were poised, ready to strike. The Armenians were not idle, however."29 Armenian volunteer squads, likewise armed, strategically deployed, and ready to die in self-defense, had succeeded in deterring the potential massacrers.

Thus, the memory of these historical experiences had prompted a significant number of Kayseri Armenians, including members of the two political parties, to procure caches of arms, handguns, and explosives, many of them quite old and rusty. These were stored in well-concealed locations. Neither the volume of the weapons nor their uneven quality, as far as their actual usefulness was concerned, nor the scant number of volunteers poised for self-defense were such as to tip the balance in case of a real clash with regular units of the Turkish armed and security forces. This being the case, the evident purpose of all these measures of arming was the hope of disabusing potential perpetrators of the notion that the Armenians, as usual, would be easy prey, and thereby to avert a great massacre-as had been done in the past. ${ }^{30}$ Of all those Armenian leaders subjected to excruciating tortures, one from Chomakhlou village ended up admitting this. "The torturers detailed for this job had stuffed excrement into his mouth, had shackled his body with iron hoops, and had lit a fire upon his chest." When he succumbed to these atrocities, he exclaimed, "We made these acquisitions [of arms] in order to avoid dying like despicable dogs." 31

Despite their turbulent history of rivalry and strife, the Dashnaks and Hunchaks, facing an imminent national calamity, set aside their differences to form a united front ${ }^{32}$ for purposes of defensive resistance. Accordingly, a joint committee was established for cooperation, while the parameters were left to be determined by the higher echelons of both parties. It is of utmost significance that the Hunchak leadership in Istanbul and that of the Dashnaks in Sivas both advised their cohorts in Kayseri "not to resort to any uprising and to comply with the demands of the government."33 The sequence of events indicates, however, that such compliance was not what the authorities wanted. Rather, the execution of their plan hinged on resistance and confrontation capable of producing violent clashes and bloodshed. The consummation of such clashes required the arousal, enlistment, and active participation of Turkish mobs, and the authorities went out of their way to attain this goal. As one chronicler writes, "The Turkish government set out to incite the Turkish people in order to secure its support in its exterminatory designs. It needed the Armenians to dare to provoke the Turks by way of an insurrection, or even a plain act of disobedience." 34 As the war progressed, in addition to the devastating military requisitions described above, the level of general depredations and the attendant verbal abuses and insults escalated ominously. 


\section{The Resort to Summary Proceedings through Court-Martial}

The central purpose of the elaborate measures of interrogation and torture detailed above was to pave the way for criminal prosecutions against those in custody. The ultimate purpose, however, appears to have been to establish a legal framework for the justification of the draconian measures soon to be launched against Kayseri's entire Armenian population. The authorities therefore needed a plethora of confessions of a particular type. All those taken into custody for possessing arms, or for presumed possession of arms, had a simple but basic justification: the CUP regime had granted to non-Muslims the right to possess such arms. When crushing the 1909 counter-revolution, the guardians of that regime had significantly benefited from the help of armed Armenian support groups. As one Kemalist deputy recalls in his memoirs, "Whether in the market, the streets, or in stores, all kinds of weapons were freely available for sale... Town criers and traveling salesmen peddling their arms with loud voices were part of this picture."35

The Armenians incurred a legal liability, however, when many of them failed to comply with the government's wartime order to surrender their arms and weapons, including knives. ${ }^{36}$ Disregarding the inveterate anxieties and premonitions about impending new massacres with which the Armenians were suffused, the authorities deliberately chose to interpret this reluctance to surrender their arms as a clear indication of an insurrectionary plan. By this time between 800 and 900 Armenians from all walks of life were incarcerated in Kayseri's notorious Depot prison. In this large, spacious, three-story military barracks that could hold as many as a thousand prisoners, the incarcerated Armenians were arranged there according to provenance. ${ }^{37}$

The Military Tribunal, an expanded version of the small court-martial instituted in Kayseri by the proclamation of general mobilization to handle minor offenses committed by the military, was formed for the express purpose of prosecuting the Armenians. It consisted of a president (retired Lieutenant-Colonel Tevfik), Major Şahab, two other military officers, the deputy public prosecutor, and a record-keeper. Except for a six-month interval in the second half of 1912, the CUP had been maintaining throughout the empire a state of siege, and hence martial law, since 19 August/1 September $1910 .{ }^{38}$ The requisite indictments were prepared, on the one hand, by Everek's kaymakam, Salihzeki, and, on the other, by Kayseri city's police chief, Zeki. The Armenians were uniformly charged with premeditated conspiracy against the Turkish army. More specifically, the two Armenian political parties of Kayseri district were, as collective entities, identified as principal agents of conspiracy; on account of their presumed consent to this conspiracy, on the other hand, the regional Armenian notables (eşraf) were charged as accessories.

The proceedings had all the characteristics of a kangaroo-court set-up. No defense counsel was allowed; the defendants were tried in groups of various sizes, each court session lasting an average of three to four hours. The standard procedure was as follows: the prosecutor would pose an accusatory question, and before the defendant could complete his answer, he would be dressed down with a torrent of new accusatory questions. The common line of defense of the accused was that their acquisition of weapons and arms was a legitimate act, since it was allowed by the new constitution. Moreover, they all maintained, these arms had come in handy when the Armenians had come to the defense of the imperiled CUP regime in 1909. But this line of defense was typically twisted by the prosecutor, when he intoned,

Against whom would you have to defend the Constitution? Of course against the other Turks. And how would you proceed? Of course by massacring the regime's opponents, 
who happen to be all Turks also. There it is. Your own explicit confession of your conspiratorial plan.

Allowed to articulate his defense, Kevork Vişabian, the top Dashnak leader among the accused, made, among others, the following statement:

Do not exaggerate the practical value of a few obsolescent and antiquated handguns and rusty bombs. They all served a mere precautionary purpose... Don't be carried away by the exertions of haphazard imagination... Is it a sin for a father or brother to be tempted to think of self-defense when he sees with his own eyes his child or sister being mutilated and butchered? Can the law ever forbid that elemental right that is granted by God, is sanctified by religion, and is found enshrined in the annals of history? Some may counter by saying, "Don't you trust the government enough to dare to organize your own defense?" The government can surely protect, provided it can jar itself loose from confusion and paralysis while it tries to maintain its authority and attends to the needs of its citizens. But we have already seen that with the outbreak of revolutionary unrest even cabinet ministers tried to save their heads. As you all know, one of the most influential one among them had sought refuge in the home of an Armenian and thereby escaped a tragedy. Esteemed judges, remain true to your calling, follow the path of justice and stop persecuting the Armenians. ${ }^{39}$

Neither this oratorical plea nor the discreet religious services held daily in the Depot barracks prison yielded any tangible results. With predictable regularity the court found the overwhelming majority of the defendants guilty as charged. The text of the verdict was published in the district's official journal in connection with the courtmartial of the first batch of defendants. ${ }^{40}$ All twelve of them were sentenced to death by hanging. The other thirty-two defendants were sentenced to various terms of hard labor and prison. In addition to the official Turkish publication of the record of conviction and sentencing, the official files of the foreign ministry of allied Imperial Germany contain the same record in German translation. ${ }^{41}$

The serial convictions, sentence renditions, and associated hangings of eventually fifty-five Armenians were staggered during the subsequent weeks, and the hangings were carried out at a locale called the Coal Pit (Kömürlük). ${ }^{42}$

The core of the verdict is encapsulated in the following two sentences:

With the intent of unleashing a general uprising against the Ottoman Empire, the revolutionary Hunchak and Dashnak Committees conspired against the government at a joint meeting convened at Bucharest. Besides resolving to incite parts of the Armenian population of the Empire against the government, the said committees also accumulated hand grenades, dynamite and other destructive weapons. ${ }^{43}$

There are three ingredients in this judgment: conspiracy, public incitement, and the accumulation of weapons and explosives (but not any use of them). Clearly the last item cannot be subject to dispute, with the caveat that it applied only to a segment of Kayseri's Armenian community. But the other two elements require closer scrutiny.

\section{The Genocidal Sequela of the Courts-Martial}

The recurrent harping on the theme of "conspiracy" as a major weapon aimed at the Armenians lends itself to projective interpretation. As Shakespeare, through Hamlet, warned with the dictum "doth protest too much," 44 the entire pattern of the exterminatory persecution of Kayseri Armenians indicates that the perpetrators were merely projecting when accusing the Armenians of conspiracy: in other words, they were ascribing to the latter plans entertained by themselves. An array of evidence underscores the relevance and significance of this social-psychological mechanism. 
Here are some examples. By governmental fiat, the matter of the wartime deportation of the Armenians had been declared a peremptory response to anticipated Armenian insurrections; as such, they were declared military business and a military responsibility. The Temporary Law of Deportation of 13/26 May 1915 explicitly stipulates this in articles 1 and, particularly, 2. Colonel Şahabeddin, referred to above, emphatically reiterated this point in cipher telegrams he sent to Colonel Recayi, his superior in Ankara, ${ }^{45}$ who had expressed his displeasure at the civilian authorities' intervention in the matter.

In early August 1915, however, at Talât Pasha's behest, military commanders were advised by a circular from the High Command that in areas outside the theaters of war, the responsibility for handling the deportations would henceforth devolve upon civilian authorities. The emerging cleavage between civilian and military authorities on this issue found its expression in several reports dispatched by Colonel Şahabeddin to his superior in Ankara, in which he complained about the instigations alleging rebellious activities by the Armenians. With special reference to such Kayseri-district villages as Erkilet and Mancusun, for example, he accused Zekâi, the district's governor, of falsely accusing the Armenians of armed assaults. This prompted Colonel Recayi, Şahabeddin's superior, to instruct him to henceforth discount civilian sources and rely only on the military ones. An integral part of these reports, prepared by the regional military authorities, were references to numerous acts of pillage, plunder, and robbery committed by the security forces harassing and tormenting the targeted Armenians. ${ }^{46}$ However, in the overall picture of a relatively well-coordinated genocide undertaking, this discordant aspect of the conduct of the region's military commanders was but an accidental aberration, due mainly to the CUP's conspiratorial secrecy.

To emphasize the supremacy of his authority over the matter of Armenian deportations and to underscore the related urgency of draconian measures, interior minister and CUP party boss Talât Pasha paid a visit to Kayseri. At a specially convened meeting to which prominent Turkish-Muslim leaders were invited, he denounced the Armenians as a disloyal (sadakatsiz) internal foe in league with the Ottoman Empire's external enemies. Therefore, he said, it had become imperative that they be expelled and deported as disloyal elements. ${ }^{47}$

For his part, Enver, minister of war and de facto commander-in-chief of the Ottoman Armed Forces, rebuked the Kayseri courts-martial for not being harsh enough, and for not sentencing all the hundreds of defendants uniformly to death by hanging. He particularly took issue with the text of the verdict, in which the victims were accused merely of having formed a revolutionary movement and of incitement against the empire's Muslims. He wanted the Military Tribunal to focus on a principal charge, that is, the aim of creating "an autonomous and independent [sic] Armenia." That charge, the focus of the Istanbul courts-martial that had simultaneously tried, convicted, and sentenced to death twenty Hunchakist leaders, ${ }^{48}$ was connected with the annex of article 54 of the Ottoman Penal Code stipulating the sentence of death. ${ }^{49}$ Enver ended his directive with the admonition that it had to be treated as a "secret matter" (sureti mahremane). Irrespective of individual merits and differences, Armenians being court-martialed within this purview were to be uniformly treated (tevhidi tatbikat) as candidates for the death penalty.

Nevertheless, the supreme authority, the CUP's so-called politburo, was growing impatient with the piecemeal and protracted handling of the 800 to 900 Armenians remanded to the courts-martial for criminal prosecution and punishment. The district's governor, Aziz Zekâi (Apaydın), a CUP leader originally from Bosnia, 
where his Christian ancestors, like so many others, had converted to Islam, was particularly restive in this respect. In tandem with local CUP functionaries, he began to agitate against the tribunal's judges, attacking them as too formalistic and hence not as efficient as they were expected to be. The CUP's Kayseri branch had already prepared a list of those Armenians they wanted liquidated wholesale and swiftly. ${ }^{50}$ But most of them were languishing in prison, either awaiting their turn for court-martial or serving out their sentences. Zekâi decided to pay a visit to the main Depot prison. Here is the narrative of one of the prisoners there, an eyewitness to that visit:

I still vividly remember his sudden appearance at our prison. Gruff-looking, he inspected the prisoners in the first and second floors without uttering a single word. As he was about to exit from the main door of the prison, he turned to his two companions and with a hateful voice intoned, "Why keep them here? Make a clean sweep of them forthwith." We overheard this deadly exhortation with dizzying gloom. ${ }^{51}$

In defiance of the verdict dispositions of the Military Tribunal, the underlings of the district governor proceeded to systematically remove almost all of the 1,095 Armenian inmates from their prison cells. Over a period of several weeks, they were tied together with heavy-duty ropes and were marched out in seventeen separate batches to the various valleys of neighboring Sivas province, where they were massacred. Several detachments of brigands (i.e., convicts released from various prisons) were deployed in the area of Kanlıdere ("Bloody Valley"), a triangular region formed by the towns of Gemerek, Şarkışla, and Aziziye, for such massacre duty. ${ }^{52}$

The final stage in the process of liquidating Kayseri district's Armenian population was the official proclamation (actually a decree) of 26 July/8 August 1915, ordering the wholesale deportation of the rest of the victim population. Like those convicted by the courts-martial, the overwhelming majority of that population perished in the process, either through massacres ${ }^{53}$ or by attrition, dying of exhaustion, disease, or starvation.

In the end, the agency of the triggering mechanism proved pivotal, as the Armenian presence in Kayseri was terminated through a cataclysm that replicated itself in many other provinces of the moribund Ottoman Empire in the relatively brief period between spring 1915 and summer 1916. But there occurred an event in Kayseri, in the aftermath of this cataclysm, that was both distinct and peculiar: a criminal investigation was initiated to identify and prosecute the ensemble of the Turkish leaders responsible for that cataclysm. The man in charge of that pre-trial investigation was the wartime mayor of Kayseri, who, remarkably, at the time of the investigation, had remained in his job as mayor. This study will conclude with an examination of the significance of this post-war Turkish attempt at retributive justice.

\section{The Aftermath: The Aborted Post-war Initiative of Retributive Justice}

Unwilling to concede and confess to a crime, perpetrators tend to resort to denial or, in other cases, to explanations that aim to justify their actions. This aim becomes most urgent with respect to the capital crime of genocide. The institution of courts-martial in Kayseri and the proceedings associated with them were initiatives intended to justify the crime of genocide in progress. Even the Turkophile Arthur Zimmermann, at the time foreign minister of Germany, in a "very confidential" communication to Count Paul Wolff-Metternich, Germany's ambassador to Ottoman Turkey, conceded that Turkey's anti-Armenian campaign, placed under the rubric of "national security," could conceivably be defended "with an appearance of legality" ("mit einem Schein des Rechtes verteidigt werden konnte"). ${ }^{54}$ Thus, in plain language, what these authorities 
needed were plausible pretexts. The errors that sometimes crept into the process, however, inevitably revealed the totally false, and even farcical, character of these pretexts. The following example illustrates this point. In its verdict of 2 June 1915, pronouncing a sentence of "death by hanging" for the first batch of the fifty-five doomed Armenians, the court-martial erroneously, or falsely, declared that "Hunchak and Dashnak party leaders had decided in a Congress in Bucharest to initiate action against the Turkish government." The fact is, however, that that congress was convened only by a faction of Hunchak party and that the Dashnaks had absolutely nothing to do with it and hence could not have participated. This falsehood found expression in the two propaganda pamphlets issued by the central government during the war. ${ }^{55}$ In commenting on one of them as a "cleverly framed" pamphlet, the veteran Austrian ambassador to Turkey, Johann Margrave von Pallavicini, wrote the following to his foreign minister in Vienna:

To massacre the men and to deport women and children who, due to lack of transport and provisions, arrive in frightfully diminishing numbers, is a procedure which not only cannot be justified, but forever will remain a blot [Schandfleck] on the reputation of the Turkish government. ${ }^{56}$

That reputation would be a test case for a succession of post-war Turkish governments desperately trying to cope with the consequences of the wartime Armenian cataclysm. Indeed, the full scale of that cataclysm came into full relief when courts-martial were established in the Ottoman capital to deal with the problem legally. (These proceedings have been detailed and analyzed in a previous article). ${ }^{57}$ Departing from this modus operandi of confining the criminal proceedings to the Ottoman capital, post-war authorities in Kayseri decided to prosecute in loco the respective Kayseri officials and their accomplices. The man responsible for this initiative was Ahmet Rifat (Çalıka), the long-sitting mayor of Kayseri city. Commenting on the attributes and virtues of this Turkish official, a Kemalist deputy wrote, "Rifat was an enlightened jurist; he was free from any kind of fanaticism... scant on words and correct in his behavior... he obeyed the dictates of his conscience allowing to determine that behavior." 58 After the advent of the Kemalist regime, Rifat was elected as a deputy to the new Grand National Assembly and was subsequently appointed to the post of minister of justice. For all these reasons, his plan to prosecute the wartime Kayseri perpetrators and the specifics of the related charges acquire inordinate significance.

In a book edited by his son and containing Rifat's memoirs, these specifics are embedded in the texts of a series of formal indictments. These legal charges were made public in 1992 and are exceptionally significant in that the issue involved touched the taboo subject of the Armenian Genocide, which had been aggressively denied throughout the entire history of modern Turkey. In separate tables included in this book one can identify all the names of the principal perpetrators in the Kayseri district, along with the specific charges and the requisite measures of punishment. Rifat indicates in a note attached to the indictments that the indictments were framed on the basis of "documents secured in the course of pre-trial investigations." 59 Foremost among the indictees were the two principal perpetrators of the cataclysm that fully merits the designation "Armenian Genocide." One of them, Salihzeki, the inexorable kaymakam of Develi (Everek), was charged with torture, bribery, and rape. The other, Zekâi, the governor of the Kayseri district, was charged with multiple murders. Three dozen other officials, particularly gendarmes of various ranks, ranking police officers, lower-level governors, CUP party functionaries, and local party leaders, identified by 
name and status, were among the indictees. The punishments proposed variably referred to articles 45, 103, and 170 of the Ottoman Penal Code, providing for sentences ranging from death to terms of hard labor.

A noteworthy aspect of this series of indictments is the prominence of charges of pillage, plunder, robbery, and thievery, not to speak of serial rape, which were depicted as crimes ancillary to that of organized mass murder. It appears that with very few exceptions, practically all the perpetrators, from the highest to the lowest rankespecially Salihzeki, the arch-perpetrator-actively engaged in this type of license, raising the fundamental issue of the role of personal incentives involving greed and cupidity in genocide. As the veteran wartime US consul at Aleppo, Jesse Jackson, reported to Washington, DC, an integral part of the organized, wholesale extermination of the Armenian population involved "a gigantic plundering scheme." 60

But, as far as the ultimate decision makers in the Ottoman capital were concerned, superseding these incentives in the first place was the more basic, pervasive, and compelling drive to radically exterminate the people subsequently to be disposed of. As Jackson was trying to inform Washington, the supreme, superordinate goal of the CUP was to deliver the "final blow to extinguish the [Armenian] race." ${ }^{\prime \prime 1}$ The explanation and the allied justification for this lethal attitude was provided by Salihzeki. When a delegation of Armenian notables was pleading with him to relent in his persecution, he responded thus:

You Armenians are progressive people, you are industrious and productive. I wish we Turks could be like you. The trouble is that these conditions are inimical with our national interests. How can we acquiesce to the fact that the Turk, the master of this land, has become your servant. The Armenians live in comfortable homes, but the Turks are confined to huts and sheds. The Armenians dress well, eat well, while the Turks have to contend with rags and dry bread. Now that the opportunity has presented itself, we are determined to annihilate you. Your sympathies for the Allied Powers make this even more expedient. Your annihilation will not be carried out quickly and swiftly but will be accompanied by torment and torture. ${ }^{62}$

The ascendancy of Kemalism in defeated and prostrate post-World War I Turkey, and its ultimate triumph, nipped in the bud any and all prosecutorial efforts. As a result, for example, Zekâi, Kayseri's district governor, first escaped to his native Bosnia to avoid prosecution, then proceeded to join the Kemalist movement. He subsequently rose to such high positions in the new Republic of Turkey as deputy in the new Grand National Assembly; twice ambassador at London, then at Moscow; and minister of public works and minister of defense. ${ }^{63}$ As to the other principal perpetrator, Salihzeki, he fled to Baku to join a new group of Turkish communists, with the aim of importing that ideology and movement into Kemalist Turkey.

\section{Conclusion}

This study has attempted to show that triggering mechanisms, often intimately connected with the outbreak of large-scale conflagrations and cataclysms, may under certain circumstances be considered necessary conditions for the explosion and consummation of the underlying conflicts. But they are not at the same time sufficient conditions. The elements of the conflict, the power relations between a potential perpetrator and a potential victim, and the level of opportunity available for the consummation of conflict are variables to factor in when assessing the matter of sufficiency. What happened in Kayseri during World War I was the sanguinary culmination $^{64}$ of a protracted historical conflict between an omnipotent state 
organization and a highly vulnerable minority group. Moreover, the advantages of the resulting power differential were monopolized by a monolithic political party that reigned supreme in directing the internal and external policies of the state. ${ }^{65}$ This exercise of supreme power by a political party could be achieved because the most powerful CUP leaders were at the same time ministers, Army commanders, and other state officials, such as provincial governors. Not only were the two pre-eminent organizers of the Armenian Genocide top CUP leaders, for example, but one of them, Talât Pasha, was interior minister and subsequently grand vizier (a sort of prime minister), while the other, Enver, was both deputy commander-in chief of the Ottoman Armed Forces and minister of defense. Both men played a decisive role in the organizational and legal arrangements that ensured the wholesale liquidation of the Armenians.

In brief, the genocide of the Armenians as enacted in Kayseri during the war, just as in other parts of the Ottoman Empire, was predicated upon such major determinants as the history of lingering Turko-Armenian conflict; a critical disparity of power relations between perpetrator and victim, yielding the vulnerability ingredient; and the optimal opportunity afforded by the war. Above all, however, it was predicated, just as in Nazi Germany, upon a fusion of government and party machineries, with the latter holding implacable sway and, accordingly, giving content and direction to that fusion. The more or less unhindered configuration of these factors was such as to ensure a very high degree of success in the implementation of the genocide. Ultimately, however, the genocidal fate of the Kayseri Armenians emerges here as a function of critically disparate power relations, as noted above. The dominant Turks took full advantage of their overwhelming power position vis-à-vis a near totally defenseless minority. The conditions of the war were such as to maximize the statutory vulnerabilities of that minority, trapped in the vortex of a consuming global war. Problems of prejudice, discrimination, and exclusion, compounded by the formal declaration of holy war, jihad, combined to aggravate the plight of the victim population. Determined to avoid any and all provocations, the bulk of that victim population tried desperately to be as accommodating as possible toward the authorities and their incremental demands. Yet all this proved futile. It may be fitting to conclude with a statement in which Henry Morgenthau, wartime US ambassador to Turkey, succinctly highlights the twin problems of vulnerability and provocation as twin pivotal factors.

In the organization of the Armenian Genocide as a whole:

Though the air all during the autumn and winter of 1914-15 was filled with premonitions of trouble, the Armenians behaved with remarkable self-restraint. For years it has been Turkish policy to provoke the Christian population into committing overt acts and then seizing upon such misbehavior as an excuse for massacres. The Armenian clergy and political leaders saw many evidences that the Turks were now up to their old tactics, and they therefore went among the people, cautioning them to keep quiet, to bear all insults and even outrages patiently, so as to not give the Moslems the opening which they were seeking... "even if they burn a few of our villages..." these leaders would say, "do not retaliate, for it is better that a few be destroyed than that the whole nation be massacred."66

\section{Notes}

1. For a pertinent analysis of this practice, see Robert Melson, "Provocation or Nationalism: A Critical Inquiry into the Armenian Genocide of 1915," in The Armenian Genocide in 
Perspective, ed. Richard Hovannisian, 61-84 (New Brunswick, NJ: Transaction Books, 1987).

2. Karl A. Schleunes, The Twisted Road to Auschwitz: Nazi Policy toward German Jews 1933-1939 (Urbana: University of Illinois Press, 1970), 245-46, 289.

3. Kemal H. Karpat, Ottoman Population 1830-1914: Demographic and Social Characteristics (Madison: University of Wisconsin Press, 1985), 8.

4. Zübeyir Kars, Milli Mücadelede Kayseri [Kayseri During the National Struggle] (Ankara: Ministry of Culture, 1993), 75.

5. Ibid.

6. Ibid.

7. Esat Uras, Tarihte Ermeniler ve Ermeni Meselesi (Ankara: Yeni Matbaa, 1950), 144; the same book appears in a revised and enlarged edition in English: Esat Uras, The Armenians in History and the Armenian Question (Ankara: Documentary Publications of Historical Research Publishing Unit, 1988), 364. The respective population figures for Kayseri district Armenians may be broken down as follows: Kayseri city, 15,000-16,000; Efkere, 2,000; Erkilet, 60; Germir, 500; Talas, 3,200; Chomaklou, 1,760; Tomarza (Göster), 8,000; Incesu, 1,100; Everek-Fenese, 8,600.

8. Malachia Ormanian, The Church of Armenia: Her History, Doctrine, Rule, Discipline, Liturgy, Literature, and Existing Condition, trans. G.M. Gregory, 2nd rev. ed by

T. Poladian (London: A.R. Mowbray, 1955), 205.

9. Vahakn N. Dadrian, "The Documentation of the World War I Armenian Massacres in the Proceedings of the Turkish Military Tribunal," International Journal of Middle East Studies 23 (1991): 549-76, 563.

10. Kapriel Takvorian, Yerazankee û Darabankee Dariner 1908-1915 [Years of Dreams and Sufferings, 1908-1915] (Cairo: Housaper, 1961), 143-44.

11. Aris Kalfaian, Chomaklou: The History of an Armenian Village, ed. M. Ekizian (New York: Chomaklou Compatriotic Society, 1982), 106. For some unexplained reason this English version has dropped the word "Dante's," which is found in the Armenian-language original. See Kalfaian, Chomaklou (New York: Gochnak Publishing House, 1930), 85.

12. According to a chronicler of these events, the man who inflicted these tortures in Kayseri's Cafer Bey police station was police captain Bessim Bey, "a savage cruel man... who tortured his victims beyond description." One such victim was Setrag Elmayan, "who lived in our street... They beat him so severely that he died... Those who lived near that police station, both Turks and Armenians, would say that they couldn't stand the cries and suffering of the prisoners who were tortured all night... several died, and others, including Parsegh Balian, contracted gangrene from the excessive bastinadoing of their feet."

Stephen G. Svajian, A Trip Through Historic Armenia (New York: Green Hill Publishing, 1977), 357.

13. Kapriel Takvorian, Korsh Kaylu Gadgher er.1915. Vugayoutunner $\hat{u}$ Dubavoroutunner [The Gray Wolf Was Enraged: Testimonies and Impressions, 1915] (Cairo: Housaper, 1953), 261-62. Unless otherwise stated, all English translations are my own.

14. Arshag A. Alboyajian, Badmoutiun Hai Gesario [History of Kayseri's Armenians], vol. 2 (Cairo: Papazian Printing House, 1937), 1442-43. This is what brigand chief Süreyya is reported to have said: "I have often been present at sessions of beating and torture. I couldn't help but admire Mourad, along with Çigdemian and Vişabian, for their bravery ... Perhaps it might be possible to extract answers from rocky stones subjected to pummeling blows but it hasn't been possible to wrench a word from them."

15. Kalfaian, Chomaklou, 101.

16. Ibid.

17. Kapriel Takvorian, Humayitch $\hat{e}$ Veradznountu [The Renaissance Is Magnificent] (Beirut: Sevan Edition, 1968), 23.

18. Vahan Elmayan, "Turk Vayrakoutiunneru Gesario Metch [Turkish Savageries in Kayseri]," Yeridasart Haiasdan (August 1920), quoted in Alboyajian, Badmoutiun, 1436-37. 
19. The older of the two, Sarkis Donigian, was the long-time director of the local Armenian high school and had a sterling reputation as a patriotic Armenian. For years he had been infusing into his pupils a spirit of dedication to Armenian culture and civilization. Upon converting, he adopted the Turkish name Haci Yusuf Kenan and became the right-hand man of Salihzeki. His junior partner, Gülbenk Bedrosian, was another teacher, a colleague of his. In fact, it was Bedrosian who finally persuaded his senior to become an informer too. Bedrosian also formally converted into Islam, adopting the Turkish name Şahabeddin Zeki. Takvorian, Humayitch, 24-30; Kalfaian, Chomaklou, 82, 102; Takvorian, Korsh Kaylu, 174-78.

20. Takvorian, Korsh Kaylu, 213, 222-24.

21. Alboyajian, Badmoutiun, 1410-11. The names of four additional informers are listed briefly in this source and are briefly described: Minas Minassian, the Hunchak leader; two Dashnaks, Kevork Yilanjian and Mihran Yazidjian; and Hovagim Yezegielian, the caretaker of Kayseri's St. Mary Armenian Church. Unlike the Hunchak leader, Yilanjian and Yazidjian could not produce the Dashnak party's membership lists, which were promptly made to disappear by the executive secretary of the party as soon as the crisis broke out.

22. Takvorian, Yerazankee, 144, 158-59.

23. Takvorian, Korsh Kaylu, 247.

24. The council chairman, Garabed Camjian, was a respected member of the Turkish municipal government and at the same time chairman of several Armenian educational and charitable organizations. Despite his manifest loyalty to the government, he was courtmartialed and hanged, along with dozens of other Armenian community and party leaders. Shortly before his execution, one of the latter rebuked him for having trusted the government and for having urged compliance. Ibid., 287.

25. V. Gesaratzee, "Gesario Yev Shurchagayeetz Aryan Dourku Hayotz Medz Yegerneen [The High Cost of Blood the Armenians of Kayseri and Its Environs Paid During the Great Calamity]," in Houshamadian Medz Yegernee 1915-1965 [Compendium on the Great Calamity], ed. Kersam Aharonian, 336-61 (Beirut: Zartonk Publications, 1965), 349.

26. The targeted victim was Hagop Urgandjian (Kayayan). Two policemen were assigned to place a bomb with a timer on the roof of his house during the night. Several other explosives were likewise planted in his vineyards, located half an hour's distance from his home.

27. Takvorian, Korsh Kaylu, 210-19, 227.

28. Ibid., 220.

29. Kalfaian, Chomaklou, 82.

30. Takvorian, Korsh Kaylu, 249-50; Humayitch, 30-31.

31. Kalfaian, Chomaklou, 115.

32. Cenani Gürbüz, Milli Mücadele 'de Develi (Everek) ve Ermeniler [Develi and the Armenians in Our National Struggle] (Ankara: Turkish Ministry of Culture, 1996).

33. Alboyajian, Badmoutiun, 1438 (original emphasis).

34. Ibid., 1436.

35. Damar Arıkoglu, Hâtıralarım [My Memoirs] (Istanbul: Pan Newspaper Printing House, 1961), 45, 47.

36. Kalfaian, Chomaklou, 102; Takvorian, Korsh Kaylu, 156, 250-51.

37. Those from Everek (Develi) and its environs were put in the space located on the left-hand side of the upper floor of the barracks, and Armenians from Kayseri city on the right-hand side. The Armenians from the environs of Kayseri city were housed on the right-hand side of the first floor; the left-hand side was converted into a prison hospital, which had none of the essentials of a normal hospital to handle many cases involving broken bones, lacerated feet, smashed bodies, and so on. Stretchers were used to carry prisoners to and from the courtroom. Ibid., 264. 
38. Vahakn N. Dadrian, "Genocide as a Problem of National and International Law: The World War I Armenian Case and Its Contemporary Legal Ramifications," Yale Journal of International Law 14 (1989): 221-334, 303 n. 316, 305 n. 331.

39. Takvorian, Korsh Kaylu, 277-78.

40. Kayseri [the official weekly of Kayseri district], 4 June 1915. The executions on the scaffold were carried out on 2 June 1915, the day the convictions and sentence renditions were officially announced. The text of the verdict can also be found in Kalfaian, Chomaklou, 139-40.

41. German Foreign Ministry Archives, A.A. Bokon (Botsehaft Konstantinopel), vol. 169, no. 407 (R14086), report of Hans Wangenheim, German ambassador to Istanbul, to German Chancellor Bethmann Hollweg, 27 June 1915.

42. Eleven people were hanged on 2/15 June 1915; one on 3/16 June; eight on 11/24 July; two on 30 July/12 August; fifteen on 31 July/13 August; seven on 20 August/2 September; one on 5/18 September; two on 13/26 September; five on 20 November/3 December; one on 9/22 November 1916; and two on 15/28 November, fifty-five in all. Gesaratzee, Gesario, 350-54; Takvorian, Korsh Kaylu, 285-382.

43. Kalfaian, Chomaklou, 139.

44. "The lady doth protest too much, me thinks." Hamlet, in Complete Works, ed. Peter Alexander (New York: Random House, 1952), 3.2.242 (reference is to act, scene, and line).

45. Archives of the Armenian Patriarchate of Jerusalem, ser. 17, file H, doc. no. 615, telegrams from Colonel Şahabeddin to Colonel Recayi, 16/29 July 1915 and 21 July/3 August 1915.

46. Ibid., file H, doc. nos. 603, 604, 606, 609, 611.

47. Hurşit Çalıka, ed., Kurtuluş Savaşında Adalet Bakanı Ahmet Rifat Çalıka'nın Anıları [The Memoirs of Ahmet Rifat Çalika, Minister of Justice during the War of Independence] (Istanbul: n. pub., 1992), 26.

48. For an analysis of the farcical aspects of this trial, see Vahakn N. Dadrian, "The Secret Young-Turk Ittihadist Conference and the Decision for the World War I Genocide of the Armenians," Holocaust and Genocide Studies 7 (1993): 173-201, 190-91.

49. Archives of the Armenian Patriarchate of Jerusalem, ser. 17, file H, doc. no. 587.

50. Takvorian, Korsh Kaylu, 280.

51. Ibid., 239-40.

52. Ibid., 296-97, 302, 313; Gesaratzee, "Gesario," 355.

53. Several survivors have recorded their eyewitness accounts of these butcheries, in which mobs enlisted from surrounding localities, carried out the massacres, some of them armed only with scythes. Kalfaian, Chomaklou, 143. A narrative by another survivor relates the ghastly carnage at a place called Moudrasin, near Gemerek village, where the victims were killed by mutilation by a mob of women armed with hatchets, axes, and vegetable knives; in all cases the victims had been rendered defenseless through the use of chains or, more commonly, ropes. Ibid.

54. Archives of the German Foreign Ministry, K 174/27; also Türkei 183/44, A26071 (R14093), report no. 1048, Zimmermann to Wolf-Metternich, 2 October 1916.

55. See, e.g., Vérité sur le mouvement révolutionnaire arménien et les mesures gouvernementales (Istanbul: 1916), 12; published also in Revue de Hongrie 19 (15 June 1917): 34-52, and in the Austrian Foreign Affairs Archives, PA X11/463, enclosure of 10 March 1916. See also Aspirations et agissements révolutionnaires des comités arméniens avant et après la proclamation de la constitution ottomane (Istanbul: Ingan, 1915).

56. Austrian Foreign Affairs Archives, PA X11/463, no. 21/P.B., Pallavicini to Zimmermann, 10 March 1916.

57. Vahakn. N. Dadrian, "The Turkish Military Tribunal's Prosecution of the Authors of the Armenian Genocide: Four Major Court-Martial Series," Holocaust and Genocide Studies 11 (1997): 28-59.

58. Arıkoglu, Hâtıralarım, 175-77.

59. Çalıka, Kurtuluş, 11, 12-13, 34-35. 
60. US National Archives, R.G. 59.867.4016/148, enclosure in report from US Ambassador Henry Morgenthau to Washington, 30 August 1915.

61. Ibid.

62. Noubar Library Archive, Paris, file no. 6 (Kayseri), report signed by five survivors of Kayseri, 25 December 1918, p. 10.

63. Ali Çetinkaya, Mülkiye Tarihi ve Mülkiyeliler [History of the Civil Service and Graduates of the Civil Service School], vol. 3 (Ankara: Mars Publishers, 1968-1969), 989-91.

64. For further study of the details of this episode of organized mass murder, the following works may be consulted: Toros M. Madaghian, Houshamadian Tomarzayee [Compendium on Tomarza] (Beirut: Donigian, 1959), 271-304, 315-30; Aleksan Krikorian, Evereg-Fenesse: Its Armenian History and Traditions, trans. R. Norsigian (Detroit: E.F. Society, 1990), 124-50; Stella Loughridge, "Facts in Regard to Armenian Atrocities in the Cesarea District, Asia Minor," in "Turkish Atrocities": Statements of American Missionaries on the Destruction of Christian Communities in Ottoman Turkey, 1915-1917, comp. James L. Barton, 116-17 (Charlotte, NC: Gomidas Institute, 1998); Clara Childs Richmond, "Cesarea and Talas: Turkish Atrocities," in "Turkish Atrocities": Statements of American Missionaries on the Destruction of Christian Communities in Ottoman Turkey, 1915-1917, comp. James L. Barton, 120-28 (Charlotte, NC: Gomidas Institute, 1998);

Theda B. Phelps, "Story of Talas 1914-17," in "Turkish Atrocities": Statements of American Missionaries on the Destruction of Christian Communities in Ottoman Turkey, 1915-1917, comp. James L. Barton, 130-42 (Charlotte, NC: Gomidas Institute, 1998).

65. Dadrian, "Secret Young-Turk Ittihadist Conference," 186-89, 194-95.

66. Henry Morgenthau, Ambassador Morgenthau's Story (New York: Doubleday, 1918), 295-96. 